\title{
Susceptibility of a number of bivalve species to the protozoan parasite Bonamia ostreae and their ability to act as vectors for this parasite
}

\author{
S. C. Culloty ${ }^{1, *}$, B. Novoa ${ }^{2}$, M. Pernas ${ }^{2}$, M. Longshaw ${ }^{3}$, M. F. Mulcahy ${ }^{1}$, S. W. Feist ${ }^{3}$, \\ A. Figueras ${ }^{2}$
}

${ }^{1}$ Dept. of Zoology and Animal Ecology, University College Cork, National University of Ireland, Lee Maltings, Prospect Row, Cork, Ireland

${ }^{2}$ Instituto Investigaciones Marinas CSIC, Eduardo Cabello 6, E-36208 Vigo, Spain

${ }^{3}$ CEFAS, Weymouth Laboratory, Barrack Rd, The Nothe, Weymouth, Dorset DT4 8 UB, United Kingdom

\begin{abstract}
The protozoan parasite Bonamia ostreae (Pichot et al., 1980) is a serious pathogen of the native European flat oyster Ostrea edulis. Field and laboratory based experiments were carried out in Ireland and Spain to investigate the susceptibility to this protozoan of the Pacific oyster Crassostrea gigas, the mussels Mytilus edulis and Mytilus galloprovincialis, the European native clam Ruditapes decussatus and the Manila clam Ruditapes philippinarum. Their ability to act as vectors or intermediate hosts was also investigated. The study corroborated previous findings that demonstrated that flat oysters can be successfully infected both naturally in the field and experimentally in the laboratory, and the pathogen can be transmitted directly between flat oysters in the laboratory. However, the other bivalves tested could not be infected with the parasite either naturally or experimentally, and these bivalves did not appear to act as vectors or intermediate hosts for the parasite. These results have implications for movements of bivalves between areas within the European Union.
\end{abstract}

KEY WORDS: Bonamia ostreae Bonamiasis - Ostrea edulis - Crassostrea gigas - Mytilus edulis - Mytilus galloprovincialis - Ruditapes decussatus - Ruditapes philippinarum . Transmission experiments . European Union directives

\section{INTRODUCTION}

The flat oyster Ostrea edulis L. is a valuable bivalve mollusc species that is harvested in all major oyster growing areas throughout Europe. A drop in production in Europe since the 1960s has been mainly attributed to 2 parasites that have affected this species with devastating results, namely Marteilia refringens (Grizel et al. 1974) and Bonamia ostreae (Pichot et al., 1980). These protozoans have been responsible for significant mortalities of up to $90 \%$ in some areas, and for a general drop in production, that has caused some oyster farmers to turn to alternative species to offset their losses.

In Europe, Bonamia ostreae was first detected in France in the late 1970s (Pichot et al. 1980). The com-

•E-mail: s.culloty@ucc.ie plete life cycle of this parasite remains uncertain. However, it appears that transmission can occur directly from oyster to oyster and that even when an area has been left fallow for a number of years the parasite persists, infecting flat oysters after they are reintroduced to the area (van Banning 1985, 1987). Three species of flat oyster, Ostrea edulis, Tiostrea chilensis (Hutton), and Ostrea puelchana, have been tested and have been found to be susceptible to this disease (Grizel et al. 1983, Bucke et al. 1984, Bougrier et al. 1986).

As direct transmission of this parasite occurs and uncertainties exist related to its life cycle, legislation has been implemented to restrict the movement of oysters within the European Union particularly from areas known to contain the disease (EU Directive 91/67). The susceptibility of other bivalves to this parasite has also been questioned: particularly those bivalves found within the same growing areas where oyster losses due 
to Bonamia ostreae have been recorded. Furthermore, the possibility that bivalves other than oysters could act as vectors or intermediate hosts of $B$. ostreae needs to be investigated, to ensure that this parasite is not transferred from one country to another within the European Union.

This study had 2 main objectives. Firstly, to determine whether a number of bivalve species such as the Pacific oyster Crassosstrea gigas (Thunberg), the European native clam Ruditapes decussatus (L.), the Manila clam R. philippinarum (Adams and Reeve), and the mussels Mytilus edulis (L.) and $M$. galloprovincialis (Lmk.) are susceptible to Bonamia ostreae following either natural or experimental exposure; and secondly to determine whether these bivalve species, after exposure to $B$. ostreae, could act as vectors or intermediate hosts for $B$. ostreae and thus infect co-habiting uninfected flat oysters

\section{MATERIALS AND METHODS}

Sites. Bivalve molluscs for the trials were obtained from a number of sites in Ireland including Cork Harbour (Bonamia ostreae present for over $10 \mathrm{yr}$ ), Tralee, Bantry Bay, Fountainstown and Sligo Bay $(B$. ostreae never detected in these areas), as well as Norfolk, England ( $B$. ostreae never detected) and Villagarcia, Galicia, Spain (B. ostreae present for over 14 yr) (Fig. 1). Experiments were carried out in Cork (Ireland) and Vigo (Spain).

Diagnosis of Bonamia ostreae. Diagnosis of B. ostreae was carried out using heart, gill or hemolymph smears or examination of histological sections (Bachère et al. 1982, Bucke \& Feist 1985). Ventricular heart tissues or pieces of gill tissue were excised, placed onto tissue paper and then dabbed onto a clean dry slide. Slides were allowed to air dry and were then fixed in methanol and stained using Hemacolor 2 and 3 (Merck). For histological examination, tissues were fixed in Davidson's solution, processed using standard techniques and $5 \mu \mathrm{m}$ sections were stained using haematoxylin and eosin. For examination of hemolymph smears, a drop of hemolymph was removed from the adductor muscle sinus, placed on a slide and the blood cells allowed to settle. Smears were fixed in methanol and stained with Hemacolor 2 and 3 .

A sub-sample of 30 oysters was taken from each population before the trials began to determine initial prevalence of infection.

Holding conditions. Field: In Cork Harbour bivalves were placed in oyster bags $(1 \times 0.5 \mathrm{~m})$ on trestles in an area that is exposed at low spring tide only. The trestles held the bags approximately $40 \mathrm{~cm}$ off the bed. Larger mesh size bags were used as the shellfish grew.

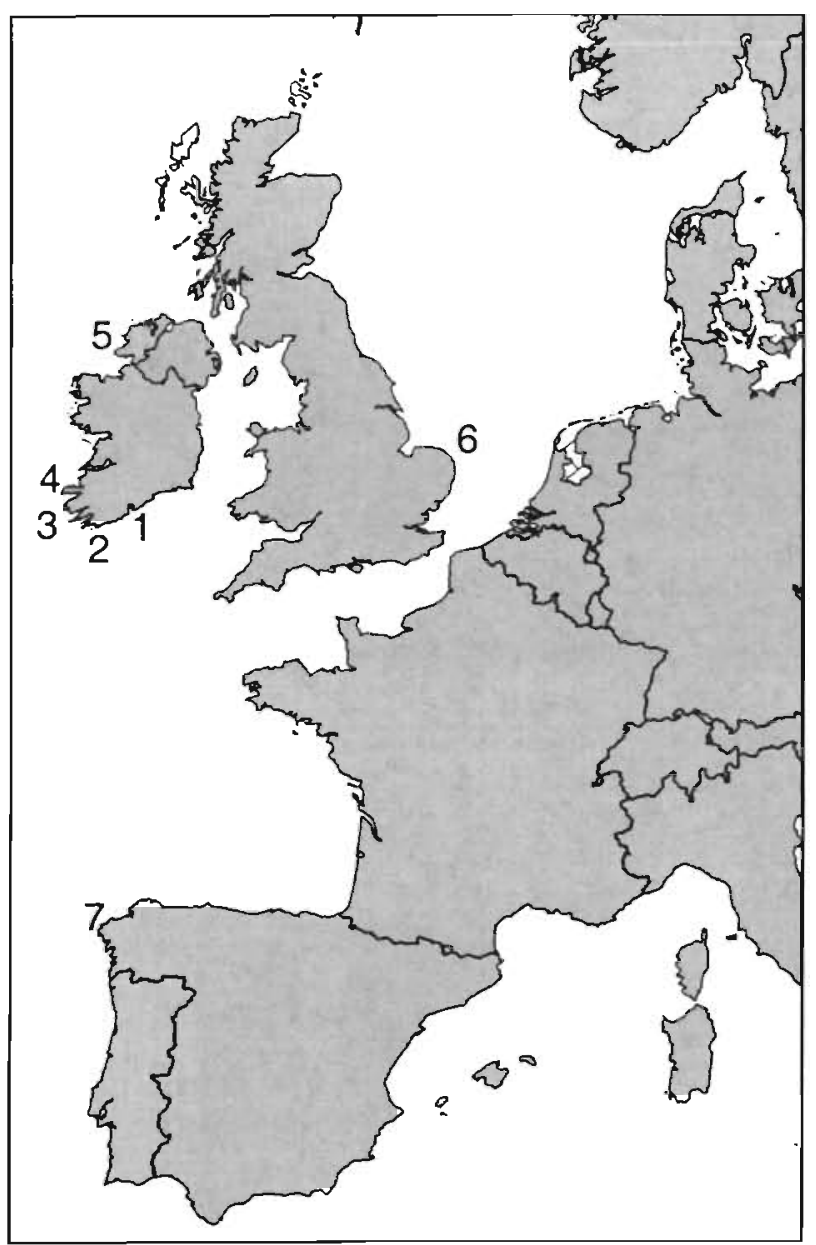

Fig. 1. Areas where trials took place and oysters were obtained. 1: Cork Harbour; 2: Fountainstown; 3: Bantry Bay; 4: Tralee; 5: Sligo Bay; 6: Norfolk 7: Vigo

Laboratory: In Cork, bivalves were held in the laboratory in $500 \mathrm{l}$ static tanks that were continuously aerated. Seawater was changed completely 3 times per week. The water was at ambient temperature and varied over the trials from 8 to $15^{\circ} \mathrm{C}$. Bivalves were fed on Tetraselmis daily. They were monitored twice daily and any moribund individuals removed. In Vigo oysters were held in the laboratory in $75 \mathrm{l}$ tanks and fed daily with Tetraselmis. Seawater was filtered and passed through a UV system before going into the tanks. Tanks were monitored twice a day and moribund individuals removed.

Infection of bivalves. Laboratory based experimental infections: To obtain high numbers of parasites for experimental infections oysters were obtained from areas where the pathogen had been present for a number of years. Prevalence and intensity of infection in the oysters was diagnosed using heart smears. Heavily infected oysters were retained and tissues homo- 
Table 1. Expts 1, 2.1-2.2, 3.1-3.2 and 4 summarising trials involving natural and experimental exposure of bivalve molluscs to the parasite Bonamia ostreae and their objectives

\begin{tabular}{|c|c|c|c|}
\hline Expt & Location & $\begin{array}{l}\text { Laboratory/ } \\
\text { field based }\end{array}$ & Objective \\
\hline 1 & Cork & Field & $\begin{array}{l}\text { Determine if a number of bivalve mollusc species could be infected } \\
\text { with } B \text {. ostreae following transfer to an oyster growing area where the } \\
\text { pathogen has been present for a number of years }\end{array}$ \\
\hline $2.1-2.2$ & Cork/Vigo & Laboratory & $\begin{array}{l}\text { Determine if a number of bivalve molluscs could be infected with } B \text {. } \\
\text { ostreae by experimental injection of a known number of viable } \\
\text { parasites in the laboratory }\end{array}$ \\
\hline $3.1-3.2$ & Cork/Vigo & Laboratory & $\begin{array}{l}\text { Determine if bivalves naturally exposed to } B \text {. ostreae in the field could } \\
\text { act as vectors or intermediate hosts for this pathogen when held in the } \\
\text { laboratory with Ostrea edulis from an oyster growing area where } B \text {. } \\
\text { ostreae has never been detected }\end{array}$ \\
\hline 4 & Cork & Laboratory & $\begin{array}{l}\text { Determine if bivalves which have been injected with } B \text {. ostreae can } \\
\text { act as vectors or intermediate hosts for the pathogen when held in the } \\
\text { laboratory with } O \text {. edulis from an oyster growing area where the } \\
\text { pathogen has never been detected }\end{array}$ \\
\hline
\end{tabular}

genised and parasites isolated according to the method of Mialhe et al. (1988). Parasite cell viability was assessed using Trypan blue exclusion. Cells that excluded the dye were regarded as viable and were counted using a Neubauer counting chamber Using this method for determining viability, cell concentration of viable parasites was adjusted using filtered seawater $(0.45 \mu \mathrm{m})$.

In Cork, the number of viable parasites injected into each oyster was adjusted to $5 \times 10^{6}$ Bonamia ostreae in $500 \mu$ filtered seawater (FSW). In Vigo the number of injected parasites was $4.15 \times 10^{6} \mathrm{~B}$. ostreae cells in $500 \mu \mathrm{FSW}$.

For injection of the parasites the bivalves were first anaesthetised using $3.5 \% \mathrm{MgCl}_{2} \cdot 6 \mathrm{H}_{2} \mathrm{O}$. The time required for anaesthesia varied from 1 to $3 \mathrm{~h}$ depending on the bivalve species. When the bivalve was anaesthetised and the shell was gaping the inoculum was injected into the mantle cavity. Animals were kept out of the water for approximately $1 \mathrm{~h}$ following injection and were then returned to aerated seawater where they were allowed to recover. The control animals were anaesthetised in a similar manner and injected with filtered seawater only.

Field based natural challenge experiments: Bivalves to be infected naturally were placed in Cork Harbour where the pathogen had been present for a number of years. They were held for up to $10 \mathrm{mo}$. Sub-samples of 30 oysters were removed after $0,1,2,5$ and 10 mo to screen for prevalence of infection.

Experiments. The following series of experiments was carried out:

Table 1 lists the experiments carried out during the study and their objectives. Table 2 lists the transmis- sion experiments carried out by natural challenge in the field and experimental infection in the laboratory. Table 3 lists the different co-habitation trials carried out between the different bivalve molluscs that had been exposed to Bonamia ostreae either naturally in the field or experimentally in the laboratory and Ostrea edulis from areas where bonamiasis has never been diagnosed.

\section{RESULTS}

\section{Isolation of parasites, assessment of viability}

Approximately $8 \times 10^{7}$ parasites were isolated from each heavily infected oyster in approximately $1 \mathrm{ml}$ of FSW. Assessment of viability indicated that $95 \%$ of the cells were viable following the isolation process in all cases.

\section{Experiment 1}

Natural transmission: to determine if a number of bivalve mollusc species could be infected with Bonamia ostreae following transfer to an area where $B$. ostreae has been present for a number of years.

Five bivalve species, Ostrea edulis, Crassostrea gigas, Ruditapes decussatus, $R$. philippinarum, and Mytilus edulis, were monitored over a $10 \mathrm{mo}$ period after being placed in a $B$. ostreae infected area (Table 4). No infection with $B$. ostreae was found in any of the sub-samples of each population taken 
Table 2. Expts 1, 2.1 and 2.2 outlining transmission experiments carried out by natural infection in the fjeld and experimental injection in the laboratory

\begin{tabular}{|c|c|c|c|c|c|c|c|}
\hline Expt & Location & $\begin{array}{l}\text { Mode of } \\
\text { transmission }\end{array}$ & $\begin{array}{l}\text { Bivalves } \\
\text { exposed } \\
\text { (number) }\end{array}$ & $\begin{array}{l}\text { Source of } \\
\text { bivalves }\end{array}$ & $\begin{array}{l}\text { Method of } \\
\text { holding }\end{array}$ & $\begin{array}{l}\text { When } \\
\text { sampled }\end{array}$ & $\begin{array}{l}\text { Method of } \\
\text { diagnosis }\end{array}$ \\
\hline 1.1 & $\begin{array}{l}\text { Cork } \\
\text { Harbour } \\
\text { - Field }\end{array}$ & Natural & $\begin{array}{l}\text { O. edulis }(327) \\
\text { M. edulis }(900) \\
\text { R. decussatus }(375) \\
\text { R. philippinarum }(336) \\
\text { C. gigas }(300)\end{array}$ & $\begin{array}{l}\text { Tralee, Ireland } \\
\text { Bantry, Ireland } \\
\text { Bantry, Ireland } \\
\text { Sligo, Ireland } \\
\text { Cork, Ireland }\end{array}$ & $\begin{array}{l}\text { Bags on trestles: } \\
327 / \mathrm{bag} \\
300 / \mathrm{bag} \\
125 / \mathrm{bag} \\
112 / \mathrm{bag} \\
75 / \mathrm{bag}\end{array}$ & $\begin{array}{l}\text { After } 0,1,2,5 \\
\text { and } 10 \text { mo } \\
\text { ( } 30 \text { bivalves } \\
\text { from each } \\
\text { group on } \\
\text { each occasion) }\end{array}$ & $\begin{array}{l}\text { Heart } \\
\text { smears }\end{array}$ \\
\hline 2.1 & $\begin{array}{l}\text { Cork } \\
\text { - Laboratory }\end{array}$ & $\begin{array}{l}\text { Experimental } \\
\text { injection: } \\
5 \times 10^{6} \mathrm{~B} \text {. } \\
\text { ostreae in } \\
500 \mu \mathrm{I} \text { FSW/ } \\
\text { oyster } \\
\text { Controls: } \\
500 \mu \mathrm{l} \text { FSW/ } \\
\text { oyster }\end{array}$ & $\begin{array}{l}\text { O. edulis }(180) \\
\text { R. decussatus }(180) \\
\text { R. philippinarum }(180) \\
\text { C. gigas }(180)\end{array}$ & $\begin{array}{l}\text { Tralee, Ireland } \\
\text { Bantry, Ireland } \\
\text { Sligo, Ireland } \\
\text { Fountainstown, } \\
\text { Ireland }\end{array}$ & $\begin{array}{l}500 \text { l aerated } \\
\text { tanks; } \\
\text { fed on } \\
\text { Tetraselmis }\end{array}$ & $\begin{array}{l}30 \text { animals } \\
\text { removed } 2 \text { wk } \\
\text { post-inoculation } \\
\text { all remaining } \\
\text { animals removed } \\
\text { after } 6 \text { mo }\end{array}$ & $\begin{array}{l}\text { Heart } \\
\text { smears }\end{array}$ \\
\hline 2.2 & $\begin{array}{l}\text { Vigo } \\
\text { - Laboratory }\end{array}$ & $\begin{array}{l}\text { Experimental } \\
\text { injection: } \\
4.15 \times 10^{4} \mathrm{~B} \text {. } \\
\text { ostreae in } \\
500 \mu \mathrm{FSW} / \\
\text { oyster } \\
\text { Controls: } \\
500 \mu \mathrm{FSW} / \\
\text { oyster }\end{array}$ & $\begin{array}{l}\text { O. edulis }(19) \\
\text { M. galloprov- } \\
\text { incialis }(20) \\
\text { O. edulis }(10)\end{array}$ & $\begin{array}{l}\text { Norfolk, UK } \\
\text { Norfolk, UK } \\
\text { Norfolk, UK }\end{array}$ & $\begin{array}{l}75 \text { l aerated } \\
\text { tanks (water } \\
\text { filtered and } \\
\text { passed through } \\
\text { UV system)i } \\
\text { fed on } \\
\text { Tetraselmis }\end{array}$ & $\begin{array}{l}\text { Hemolymph } \\
\text { tested after } \\
7 \text { wk, all ani- } \\
\text { mals removed } \\
\text { by } 6 \text { mo }\end{array}$ & $\begin{array}{l}\text { Hemo- } \\
\text { lymph } \\
\text { smears and } \\
\text { histology }\end{array}$ \\
\hline
\end{tabular}

Table 3. Expts 3.1, 3.2 and 4 outlining co-habitation trials carried out between Ostrea edulis, Mytilus edulis, M. galloprovincialis, Ruditapes decussatus, $R$. philippinarum and Crasssostrea gigas that had been exposed to Bonamia ostreae either naturally in the field or experimentally in the laboratory and $O$. edulis from areas where bonamiasis has never been diagnosed

\begin{tabular}{|c|c|c|c|c|c|c|c|c|c|}
\hline Expt & Location & $\begin{array}{l}\text { Method of } \\
\text { transmission }\end{array}$ & $\begin{array}{l}\text { Bivalves } \\
\text { exposed }\end{array}$ & $\begin{array}{l}\text { Method of } \\
\text { exposure }\end{array}$ & $\begin{array}{l}\text { Held } \\
\text { with }\end{array}$ & Source & $\begin{array}{l}\text { Holding } \\
\text { facilities }\end{array}$ & Sampling & $\begin{array}{l}\text { Method of } \\
\text { diagnosis }\end{array}$ \\
\hline 3.1 & $\begin{array}{l}\text { Cork } \\
\text { - Laboratory }\end{array}$ & Co-habitation & $\begin{array}{l}\text { O. edulis } \\
(150) \\
M . \text { edulis } \\
(150) \\
\text { R. decuss- } \\
\text { atus }(150) \\
\text { R. philipp- } \\
\text { inarum (150) } \\
\text { C. gigas } \\
(150)\end{array}$ & $\begin{array}{l}\text { Natural } \\
\text { - Field }\end{array}$ & $\begin{array}{l}\text { O. edulis } \\
(87) \\
0 . \text { edulis } \\
(87) \\
0 . \text { edulis } \\
(87) \\
0 . \text { edulis } \\
(87) \\
0 . \text { edulis } \\
(87)\end{array}$ & $\begin{array}{l}\text { L. Foyle, } \\
\text { Ireland }\end{array}$ & $\begin{array}{l}500 \text { l aerated } \\
\text { tanks, at } \\
\text { ambient } \\
\text { temperature } \\
\text { and fed on } \\
\text { Tetraselmis }\end{array}$ & $\begin{array}{l}\text { Moribund } \\
\text { animals } \\
\text { removed } \\
\text { throughout } \\
\text { trial, all } \\
\text { remaining } \\
\text { animals } \\
\text { removed } \\
\text { after } 6 \text { mo }\end{array}$ & $\begin{array}{l}\text { Heart } \\
\text { smears }\end{array}$ \\
\hline 3.2 & $\begin{array}{l}\text { Vigo } \\
\text { - Laboratory }\end{array}$ & Co-habitation & $\begin{array}{l}\text { M. gallo- } \\
\text { provinci- } \\
\text { alis }(21)\end{array}$ & $\begin{array}{l}\text { Natural } \\
\text { - Field }\end{array}$ & $\begin{array}{l}\text { O. edulis } \\
\text { (25) }\end{array}$ & $\begin{array}{l}\text { Norfolk, } \\
\text { UK }\end{array}$ & $75 \mathrm{l}$ tanks & $"$ & $\begin{array}{l}\text { Hemolymph } \\
\text { smears and } \\
\text { histology }\end{array}$ \\
\hline 4 & $\begin{array}{l}\text { Cork } \\
\text { - Laboratory }\end{array}$ & Co-habitation & $\begin{array}{l}\text { O. edulis } \\
(150) \\
\text { R. decuss- } \\
\text { atus }(150) \\
\text { R. philipp- } \\
\text { arum }(150) \\
\text { C. gigas } \\
(150)\end{array}$ & $\begin{array}{l}\text { Experimen- } \\
\text { tal injec- } \\
\text { tion } 5 \times 10^{6} \\
\text { B. ostreae/ } \\
500 \mu \text { FSW/ } \\
\text { oyster }\end{array}$ & $\begin{array}{l}\text { O. edulis } \\
(100) \\
0 . \text { edulis } \\
(100) \\
0 . \text { edulis } \\
(100) \\
0 . \text { edulis } \\
(100)\end{array}$ & $\begin{array}{l}\text { Tralee, } \\
\text { Ireland }\end{array}$ & $\begin{array}{l}500 \mathrm{l} \text { aerated } \\
\text { tanks, at } \\
\text { ambient } \\
\text { temperature } \\
\text { and fed on } \\
\text { Tetraselmis }\end{array}$ & $"$ & $\begin{array}{l}\text { Heart } \\
\text { smears }\end{array}$ \\
\hline
\end{tabular}


Table 4. Monitoring (\% prevalence of infection and \% cumulative mortality) of Ostrea edulis, Mytilus edulis, Ruditapes decussatus, R. philippinarum, and Crasssostrea gigas at 0,1,2, 5, and 10 mo after transfer to an oyster growing area (Cork Harbour, Ireland) where Bonamia ostreae has been present for over $10 \mathrm{yr}$

\begin{tabular}{|c|c|c|c|c|c|c|c|c|c|c|}
\hline \multirow[t]{2}{*}{ Species } & \multirow[t]{2}{*}{$\mathrm{N}$} & \multirow{2}{*}{$\begin{array}{c}0 \text { mo } \\
\text { Prev. of } \\
\text { infection } \\
(\%)\end{array}$} & \multicolumn{2}{|c|}{$1 \mathrm{mo}$} & \multicolumn{2}{|c|}{$2 \mathrm{mo}$} & \multicolumn{2}{|c|}{$5 \mathrm{mo}$} & \multicolumn{2}{|c|}{$10 \mathrm{mo}$} \\
\hline & & & $\begin{array}{c}\text { Prev. of } \\
\text { infection } \\
(\%)\end{array}$ & $\begin{array}{c}\text { Cum. } \\
\text { mortality } \\
(\%)\end{array}$ & $\begin{array}{c}\text { Prev. of } \\
\text { infection } \\
(\%)\end{array}$ & $\begin{array}{c}\text { Cum. } \\
\text { mortality } \\
(\%)\end{array}$ & $\begin{array}{c}\text { Prev. of } \\
\text { infection } \\
(\%)\end{array}$ & $\begin{array}{c}\text { Cum. } \\
\text { mortality } \\
(\%)\end{array}$ & $\begin{array}{c}\text { Prev of } \\
\text { infection } \\
(\%)\end{array}$ & $\begin{array}{c}\text { Cum. } \\
\text { mortality } \\
(\%)\end{array}$ \\
\hline \multicolumn{11}{|l|}{ Expt 1} \\
\hline O. edulis & 327 & 0 & 0 & 9.1 & 0 & 14.3 & 0 & ND & 25.0 & 24.7 \\
\hline$M$. edulis & 900 & 0 & 0 & 1.6 & 0 & 2.0 & 0 & ND & 0 & 7.2 \\
\hline$R$. decussatus & 375 & 0 & 0 & 1.6 & 0 & 2.7 & 0 & ND & 0 & 19.3 \\
\hline R. philippinarum & 336 & 0 & 0 & $92.3^{\mathrm{d}}$ & 0 & 2.9 & 0 & ND & 0 & 10.0 \\
\hline C. gigas & 300 & 0 & 0 & 0 & 0 & 0.3 & 0 & 0.3 & 0 & 0.3 \\
\hline
\end{tabular}

before relaying took place. Over the 10 mo period 5 sub-samples of the bivalves were taken to monitor prevalence of infection. After 1 mo the Manila clams suffered very heavy mortalities of $92.3 \%$ and had to be replaced with a new consignment of clams. The cause of these mortalities was not determined but similar losses occurred in the hatchery of origin at the time. Up to and including $5 \mathrm{mo}$ after transfer none of the bivalves showed any infection with $B$. ostreae following monitoring with heart smears However, when screened after 10 mo the flat oysters that had survived showed a $25 \%$ prevalence of infection. All other species remained uninfected. The flat oysters also showed the highest cumulative mortality at $24.7 \%$ over the 10 mo trial period. Cumulative mortalities in the other bivalves varied from 0.3 to $19.3 \%$.

\section{Experiments 2.1-2.2}

Experimental transmission: to determine if a number of bivalves could be infected with Bonamia ostreae following injection with the parasite.

In parallel experiments in Cork and in Vigo, Ostrea edulis, Mytilus galloprovincialis, Ruditapes decussatus, R. philippinarum and Crassostrea gigas, obtained from areas where the disease has never been diagnosed, were held in the laboratory and individuals injected with a known dose of viable parasites in filtered seawater (Table 5). No infection with Bonamia ostreae was found in any of the sub-samples taken at the beginning of the trial. Moribund animals were sacrificed during the course of the experiments and examined for $B$. ostreae. The moribund flat oysters showed

Table 5. Monitoring over a 6 mo period (\% prevalence of infection and \% cumulative mortality) of Ostrea edulis, Mytilus galloprovincialis, Ruditapes decussatus, $R$. philippinarum, and Crasssostrea gigas, following injection of each animal with a known number of viable Bonamia ostreae cells

\begin{tabular}{|c|c|c|c|c|c|}
\hline \multirow[t]{2}{*}{ Species } & \multirow[t]{2}{*}{$N$} & \multicolumn{2}{|c|}{ Moribund animals (during trial) } & \multicolumn{2}{|c|}{ Survivors } \\
\hline & & $\begin{array}{l}\text { Cumulative } \\
\text { mortality }(\%)\end{array}$ & $\begin{array}{l}\text { Prevalence of } \\
\text { infection }(\%)\end{array}$ & $\begin{array}{c}\text { Survivors } \\
(\%)\end{array}$ & $\begin{array}{l}\text { Prevalence of } \\
\text { infection }(\%)\end{array}$ \\
\hline \multicolumn{6}{|l|}{ O. edulis } \\
\hline Expt 2.1 (Cork) & 150 & 53.0 & 31.2 & 46.7 & 80.4 \\
\hline Expt 2.2 (Vigo) & 19 & 5.5 & 100 & 94.5 & 29.4 \\
\hline \multicolumn{6}{|c|}{ M. galloprovincialis } \\
\hline Expt 2.2 (Vigo) & 20 & 40.0 & 0 & 60.0 & 0 \\
\hline \multicolumn{6}{|l|}{ R. decussatus } \\
\hline Expt 2.1 (Cork) & 150 & 25.0 & 0 & 75.0 & 0 \\
\hline \multicolumn{6}{|l|}{ R. philippinarum } \\
\hline Expt 2.1 (Cork) & 150 & 85.8 & 0 & 13.3 & 0 \\
\hline \multicolumn{6}{|l|}{ C. gigas } \\
\hline Expt 2.1 (Cork) & 150 & 4.2 & 0 & 95.8 & 0 \\
\hline
\end{tabular}


31.2 and $100.0 \%$ prevalence of infection respectively in the Cork and Vigo laboratories. At the end of the 6 mo trial the remaining live oysters had 80.4 and $29.4 \%$ prevalence of infection respectively. No $B$. ostreae were found in the mussels, clams and Pacific oysters either during or at the end of the trials. High cumulative mortalities occurred in Cork in the Manila clams at $85.8 \%$ and were lowest in one group of flat oysters at $5.5 \%$ and Pacific oysters at $4.2 \%$. The high mortalities in the Manila clams appeared to be a result of the stress induced by the holding conditions and frequent handling.

\section{Experiments 3.1-3.2}

Cohabitation experiments: to determine if naturally exposed bivalves can act as vectors for Bonamia ostreae.

In Expt 3.1, flat oysters, mussels, clams and Pacific oysters that were held in an area in Cork Harbour where Bonamia ostreae is present were returned to the laboratory in Cork after 10 mo (Table 6). The flat oysters had a $25 \%$ prevalence of infection on being returned to the laboratory but $B$. ostreae was not diagnosed in the other species (Table 4). These bivalves were held with groups of flat oysters from an area not previously diagnosed with the disease. After 6 mo cohabitation the flat oysters that had been naturally infected in the wild showed a $66.7 \%$ prevalence of infection. The group from an area free of $B$. ostreae held with them showed a $46.6 \%$ prevalence of infection. B. ostreae was not detected in the other bivalves that had been held in the infected area nor in the flat oysters held with them.

Expt 3.2 took place in the laboratory in Vigo. Naturally exposed Mytilus galloprovincialis were held with
Ostrea edulis from an area where the disease has never been diagnosed. No infection was found in either group during or at the end of the 6 mo experimental period.

\section{Experiment 4}

Cohabitation experiment: to determine if experimentally injected bivalves can act as vectors or intermediate hosts for Bonamia ostreae.

In Expt 4, flat oysters, clams and Pacific oysters were injected with a known number of parasites and held with groups of flat oysters that came from an area where Bonamia ostreae has never been detected (Table 7). All species had been screened at the beginning of the trial and no infection was detected. After 6 mo of co-habitation the experimentally infected oysters had an $80.4 \%$ prevalence of infection and the flat oysters held with them had a $22.1 \%$ prevalence. $B$. ostreae was not detected in any of the other species injected with the parasite nor in flat oysters held with them.

\section{DISCUSSION}

It has been known for a number of years that the flat oyster Ostrea edulis can be successfully infected with Bonamia ostreae following either experimental injection in the laboratory or natural transmission in the field, and that transmission occurs directly when infected and uninfected oysters are held together (Bachère et al. 1982, Poder et al. 1982, Tigé et al. 1982, Tigé \& Grizel 1984, Elston et al. 1986, Montes 1991). These results were corroborated by the present study.

Table 6. Results of laboratory-based monitoring of co-habitation trials involving Ostrea edulis, Mytilus edulis, Ruditapes decussatus, $R$. philippinarum, Crasssostrea gigas, and Mytilus galloprovincialis, all exposed to the pathogen Bonamia ostreae in the field and held with groups of $O$. edulis from an area where bonamiasis has never been detected. ND: no data

\begin{tabular}{|c|c|c|c|c|c|c|c|}
\hline \multirow[t]{2}{*}{ Species } & \multirow[t]{2}{*}{$N$} & \multicolumn{2}{|c|}{ Cumulative mortality $(\%)$} & \multicolumn{2}{|c|}{$\begin{array}{c}\text { Prevalence of infection } \\
\text { during the trial }(\%)\end{array}$} & \multicolumn{2}{|c|}{$\begin{array}{l}\text { Prevalence of infection } \\
\text { at the end of } 6 \text { mo }(\%)\end{array}$} \\
\hline & & $\begin{array}{l}\text { Uninfected } \\
\text { O. edulis }\end{array}$ & $\begin{array}{l}\text { Infected } \\
\text { bivalve }\end{array}$ & $\begin{array}{l}\text { Uninfected } \\
\text { O. edulis }\end{array}$ & $\begin{array}{l}\text { Infected } \\
\text { bivalve }\end{array}$ & $\begin{array}{l}\text { Uninfected } \\
\text { O. edulis }\end{array}$ & $\begin{array}{l}\text { Infected } \\
\text { bivalve }\end{array}$ \\
\hline \multicolumn{8}{|l|}{ Expt 3.1 (Cork) } \\
\hline O. edulis & 120 & 19.5 & 91.6 & ND & 56.5 & 46.6 & 66.7 \\
\hline M. edulis & 120 & 17.0 & 25.8 & 0 & 0 & 0 & 0 \\
\hline R. decussatus & 120 & 9.2 & 8.1 & 0 & 0 & 0 & 0 \\
\hline R. philippinarum & 120 & 2.3 & 95.0 & 0 & 0 & 0 & 0 \\
\hline C. gigas & 120 & 2.5 & 0 & 0 & 0 & 0 & 0 \\
\hline \multicolumn{8}{|l|}{ Expt 3.2 (Vigo) } \\
\hline M. galloprovincialis & 21 & ND & 0 & 0 & 0 & 0 & 0 \\
\hline
\end{tabular}


Table 7. Results of laboratory-based monitoring (\% prevalence of infection and \% cumulative mortality) of co-habitation trials involving Ostrea edulis, Ruditapes decussatus, $R$. philippinarum, and Crasssostrea gigas all experimentally injected with the pathogen Bonamia ostreae and held with groups of $O$. edulis from an area where bonamiasis has never been detected

\begin{tabular}{|c|c|c|c|c|c|c|c|}
\hline \multirow[t]{2}{*}{$\begin{array}{l}\text { Injected } \\
\text { species }\end{array}$} & \multirow[t]{2}{*}{$\mathrm{N}$} & \multicolumn{2}{|c|}{ Cumulative mortality $(\%)$} & \multicolumn{2}{|c|}{$\begin{array}{l}\text { Prevalence of infection } \\
\text { during the trial }(\%)\end{array}$} & \multicolumn{2}{|c|}{$\begin{array}{l}\text { Prevalence of infection } \\
\text { at the end of the trial } \%\end{array}$} \\
\hline & & $\begin{array}{l}\text { Injected } \\
\text { bivalve }\end{array}$ & $\begin{array}{l}\text { Uninfected } \\
\text { O. edulis }\end{array}$ & $\begin{array}{l}\text { Injected } \\
\text { bivalve }\end{array}$ & $\begin{array}{l}\text { Uninfected } \\
\text { O. edulis }\end{array}$ & $\begin{array}{l}\text { Injected } \\
\text { bivalve }\end{array}$ & $\begin{array}{l}\text { Uninfected } \\
O \text {. edulis }\end{array}$ \\
\hline \multicolumn{8}{|l|}{ Expt 4 (Cork) } \\
\hline O. edulis & 150 & 53.3 & 32.0 & 31.2 & 12.5 & 80.4 & 22.1 \\
\hline R. decussatus & 150 & 25.0 & 31.0 & 0 & 0 & 0 & 0 \\
\hline R. philippinarum & 150 & 85.8 & 10.0 & 0 & 0 & 0 & 0 \\
\hline C. gigas & 150 & 4.2 & 5.0 & 0 & 0 & 0 & 0 \\
\hline
\end{tabular}

The susceptibility of a number of bivalve species including Crassostrea gigas, Mytilus edulis, M. galloprovincialis, Ruditapes decussatus and $R$. philippinarum to Bonamia ostreae was investigated. Following natural exposure or experimental injection of parasites the disease did not develop in any of these species. These results would indicate that culturing any of these species in close proximity to $B$. ostreae infected flat oysters is possible and these species will not develop the disease. The basis of this 'resistance' or lack of susceptibility needs to be investigated further. Several authors have previously indicated that $B$. ostreae has not been detected in a number of bivalve species such as mussels $M$. edulis, the cockle Cerastoderma edule (L.), the native clam, $R$. decussatus and the Manila clam $R$. philippinarum (Balouet \& Poder 1983, van Banning 1985, Tigé et al. 1987. Grizel et al. 1988, van Banning 1990). Figueras \& Robledo (1994) found that $B$. ostreae in flat oysters in Galicia does not infect neighbouring $M$. galloprovincialis. Renault et al. (1995) were unable to experimentally induce an infection by inoculation of purified parasites into Pacific oysters.

Furthermore, it appears that these bivalve species cannot act as either vectors or intermediate hosts for this parasite, as no infection occurred in any flat oysters that were held with these species for up to 6 mo following either natural or experimental exposure to Bonamia ostreae. This would indicate that these species would not be responsible for the spread of the disease.

These results are relevant to the movement of a number of bivalve species within the European Union, particularly those originating from areas where Bonamia ostreae is present. In this study under a variety of conditions, in both the laboratory and the field, a number of bivalve species did not act as vectors for the protozoan parasite $B$. ostreae nor did they appear to be susceptible to this parasite. The fact that questions still remain in relation to certain aspects of the life cycle of $B$. ostreae and presently available diagnostic techniques may have their limitations should be taken into consideration. However, when shellfish are cultured and moved under conditions comparable to those used in these experiments it is unlikely that the spread of $B$. ostreae will occur.

Acknowledgements. This work was supported by European Union FAIR contract 94C 85/13

\section{LITERATURE CITED}

Bachère E, Durand JL, Tigé G (1982) Bonamia ostreae (Pichot et al., 1979) parasite de l'hûitre plate: comparison de deux methodes de diagnostic. Conseil pour l'exploration de la mer, C.M. 1982/F:28, Copenhagen

Balouet G, Poder M (1983) Bonamia, a threat for oyster stocks. Proceedings of the 14 th Conference of the Shellfish Association, London, p 74-83

Bougrier S, Tigé G, Bachère E, Grizel H (1986) Ostrea angasi. acclimatization to French coasts. Aquaculture 58:151-154

Bucke D, Hepper B, Key D, Bannister RCA (1984) A report on Bonamia ostreae in Ostrea edulis in the UK. ICES Publ CM $1984 / \mathrm{K}: 9,1-7$

Bucke D, Feist S (1985) Bonamiasis in the flat oyster Ostrea edulis with comments on histological techniques. In: Ellis AE (ed) Fish and shellfish pathology. Academic Press, London, p $387-392$

Elston RA, Farley CA, Kent ML (1986) Occurrence and significance of bonamiasis in European flat oysters Ostrea edulis in North America. Dis Aquat Org 2:49-54

Figueras A, Robledo JAF (1994) Bonamia ostreae present in flat oysters (Ostrea edulis) does not infect mussels (Myti)us galloprovincialis). Bull Eur Assoc Fish Pathol 14(3):98-99

Grizel H, Comps M, Bonami JR, Cousserans F, Duthoit JL, Le Pennec MA (1974) Recherche sur l'agent de la maladie de la glande digestive de Ostrea edulis Linné. Bull Inst Pêches Marit Maroc 240:7-30

Grizel H, Comps M, Raguennes D, Leborgne Y, Tigé G, Martin AG (1983) Bilan des essais d'acclimation d'Ostrea chilensis sur les côtes de Bretagne. Rev Trav Inst Pêches Marit 46(3):209-225

Grizel H, Mialhe E, Chagot D, Boulo V, Bachère E (1988) Bonamiasis: a model study of diseases in marine molluscs Am Fish Soc Spec Publ 18:1-4

Mialhe E, Bachère E, Chagot D, Grizel H (1988) Isolation and purification of the protozoan Bonamia ostreae (Pichot et al., 1980) a parasite affecting the flat oyster Ostrea edulis L. Aquaculture 71:293-299 
Montes $J$ (1991) Lag time for the infestation of flat oyster (Ostrea edulis) by Bonamia ostreae in estuaries of Galicia (N.W. Spain). Aquaculture 93:235-239

Pichot Y, Comps M, Tigé G, Gruzel H, Rabouin M (1980) Recherches sur Bonamia ostreae gen n., sp. n., parasite nouveau de l'hûitre plate Ostrea edulis L. Rev Trav Inst Pêches Marit 43(1): 131-140

Poder M, Cahour A, Balouet G (1982) Hemocytic parasitosis in European oyster Ostrea edulis L. pathology and contamination. In: Payne CC, Burges HD (eds) Proceedings of the 15th Annual Meeting of the Society for Invertebrate Pathology, Brighton, p 254-257

Renault T, Cochennec N, Grizel H (1995) Bonamia ostreae, parasite of the European flat oyster, Ostrea edulis, does not experimentally infect the Japanese oyster, Crassostrea gigas. Bull Eur Assoc Fish Pathol 15(3):78-80

Tigé G, Grizel H (1984) Essai de contamination d'Ostrea edulis Linné par Bonamia ostreae (Pichot et al. 1979) en rivière de Crach (Morbihan). Rev Trav Inst Pêches Marit 46(4):307-314

Editorial responsibility: Albert Sparks,

Seattle, Washington, USA
Tigé G, Grizel H, Rabouin MA, Cochennec N, Audic G, Langlade A (1982) Maladie hemocytaire de l'húitre plate causée par Bonamia ostreae. Evolution de la situation epizootiologique en Bretagne au cours de l'année 1981 Sci Pèche 328:3-13

Tigé G, de Kergariou G, Audic G (1987) Evolution de la situation épidémiologique consécutive a la présence de Bonamia ostreae depuis 1979. Groupe de travail sur Bonamia ostreae, La Tremblade, 27/29 Avril 1987

Van Banning P (1985) Control of Bonamia in Dutch oyster culture. In: Ellis AE (ed) Fish and shellfish pathology. Academic Press, London, p 393-396

Van Banning P (1987) Further results of the Bonamia ostreae challenge tests in Dutch oyster culture. Aquaculture 67: $191-194$

Van Banning P (1990) The life cycle of the oyster pathogen Bonamia ostreae with a presumptive phase in the ovarian tissue of the European flat oyster, Ostrea edulis. Aquaculture 84:189-192

Submitted: October 30, 1997; Accepted: February 1, 1999 Proofs received from author(s): June 14, 1999 